\title{
The Role of Higher Education in Tourism Village Capacity Development
}

\author{
Fetty Asmaniati, Husen Hutagalung, and Triana Rosalina Dewi
}

\begin{abstract}
This article emphasizes on the role or social responsibility of higher education as an agent of change. Community-based tourism in the form of tourism village badly requires such roles and responsibilities of higher education institution, especially the tourism higher education institutions. This institution shall promote its existence in escorting, supervising and even enhancing community capacity both formatively and substantively, also serving as social, economic and cultural processes towards community empowerment through community-based tourism activities.
\end{abstract}

Keywords-component; formatting; style; styling; insert

\section{INTRODUCTION}

\section{A. Background}

Community-based tourism has been a subject of discussion for the last few years. This idea is in line with the ideal expectations of tourism development that focuses on the welfare of whole communities. It makes Community based Tourism (CBT) the primary theme of sustainable development in tourism especially for the countries with tourism as their main priorities. As a country that actively develops its tourism sector, Indonesia believes that CBT can serve as top priority to promote the whole community welfare, as well as to strengthen the moral development of social economy. Along with the increasing awareness of the global environment, there is a trend of changing exploitative tourism into sustainable tourism. In this case, the government policy on tourism aims at developing tourism as a major sector in order to earn more national income, stimulate the economy, increase local revenue, empower people's economy, expand employment, provide business opportunities and improve people's welfare by maintaining the national identity, religious values as well as preserving the environment quality.

Tourism village is one of the representations of CBT development. This concept is still considered as the hot media discussion as well as interesting research themes for both nongovernmental organizations and universities. It is owing to the fact that tourism village is not only actual topics for targeted social development, but it is also a strategic and dilemmatic issue for rural tourism regarding various pragmatic needs in it. It means that, in one side, the development of rural tourism serves as an ideal rural community empowerment. On the other hand, this program presents some dilemma since it is just one kind of formality where the goals and objectives are irrelevance with community-based tourism concept. Moreover, sometimes this program do not consider society as a subject, local people merely function as the object of development in the next activity instead. Those problems are sometimes deeply rooted in the limited capacity of human resources of the village, or limited access to the relevant stakeholders.

Based on the previous issues, higher education institution, as one of the stakeholders, has strategic roles in its existence as an agent of change in capacity building or community development especially for human resources in the tourism village. Despite the frequent or varied capacity building activities, it apparently still needs a proper development with emphasize on building community-based tourism village with local participation.

\section{B. Research Problems}

The identifications of the research problem are: (1) higher education's role in community service is not maximum yet . (2) Plenty of tourist village development sets local communities as merely formative components. (3) It is getting urgent to develop a development concept of tourism village-based participation of local communities. From the identification of those problems, the problem formulation of this research is: What is the role of higher education in the development of community capacity building in tourism village with local participation? The significance of this research is: in order to answer the urgent needs and anticipate the development of the Indonesian tourism, it is high time to improve community capacity involving in the tourism industry sector, particularly for local communities in the traditional tourism village area. It is due to the fact that there are still many human resources especially in local communities with lack of empowerment to face and obtain optimal opportunity to enjoy the impact of tourism development in their region.

\section{LITERATURE REVIEW}

\section{A. Community empowerment}

Empowerment is a process toward independence in strengthening society's bargaining position, the suppressive forces in all areas and sectors of life. Community empowerment is an attempt to create or enhance community capacity, both individually and collectively, to solve various problems related to efforts to improve the quality of life, independence and well-being. Community empowerment requires a major involvement of the local government and other parties to provide opportunities and ensure the sustainability of the achieved results. Empowerment also serves as a process of decision-making for people who consistently implement the decision. People who have reached a collective goal are empowered by their independence, it is 
even a must to empower through their own efforts and the accumulation of knowledge, skills and other resources in order to achieve their goals without relying on external aid.

However, McArdle implies it is not for the purpose, but their importance lies in the decision-making process (Hikmat, 2010: 2). The purpose of empowerment refers to circumstances or results to be achieved by a social change of empowered community, the power or the knowledge and capability in fulfilling their needs whether physical, economic, social such as confidence, ability to convey their aspirations, livelihood, social activities involvement and

independence in carrying out the life tasks (Anwar, 2007). Empowerment is primarily intended to help clients gain the power to make decisions and determine what actions he would have done related to them, including reducing barriers to personal and social effects of the action (Adi, 2013).

\section{B. The phenomenon of Tourism}

Tourism is basically all activities as a result of people's travelling individually or in groups with variety of purposes, except to settle down and earn a living (IUOTO 1968). As a system, tourism includes activities prior to the trip, during the trip, or the activities relating to the upstream and downstream linkages as well as the use of facilities and necessary infrastructure(Pitana, 2006: 7).

The word tourism or "pariwisata" is derived from the Sanskrit word, which has two words, namely "Pari" which means all, whole, or full, and "wisata" which means a trip or travel (Pambudi, 1998: 8), so ethimologically the term "pariwisata" can be defined as something connected with trips to recreation, tourist resorts and tourism (Pendit., 1967: 37). In Indonesia the term "pariwisata" is said to be firstly used by the late former President Soekarno, in a conversation as the equivalent of the term Tourisme (Soekadijo, 1997: 1). There are many definitions of the word "tourism", one of them isis that tourism is, the whole of the symptoms caused by the trip, and the habitation of strangers, and the provision of temporary shelter, provided that it is not permanent settlement and do not earn revenue from temporary activities (Yoeti, 1983: 106). Tourism can also be defined as the activities of a person who travels for pleasure, curiosity, and because no other jobs are better done (Lunberg, 1997: 13).

In some cases that occur in the traditional village, tourism activity often only makes the local community as an attraction, or exploitative appeal. The worse is that most exploitation carried out by outsiders do not at least make a positive contribution, both economically and socially (Sophian, 1991: 36). For example in Baduy village, local people involved in tourism activities do not get or have a strong portion, in determining or setting the activities (Kompas, October 13, 2004). It can be seen when the tourists come, the local guides who do not belong to the local population handle the group. Even there some merchants who sell the needs of travelers in the Baduy Dalam are not resident of the community. (Kompas, 21 April 2006). This phenomena also occurs in other traditional villages, such as the traditional village communities $O$ sing tribe in Kemireng village, Banyuwangi (Suara Karya, May 12,
2006). Osing tribe village was promoted by Banyuwangi government in 2002 as one tourist destination. It is expected to

increase or even empower the traditional society, through tourism activities. But the reality is actually far from expectations as parties outside the community and local government are becoming more dominant, they can reap massive profits in selling Osing tribe as tourism commodities (The Jakarta Post, April 10, 2006).

Local communities, especially the indigenous people who live in tourist areas, are one of the key players in the tourism activities since they will provide most attractions as well as determine the quality of tourism products (Weber, 2007: 23). Relations between tourists and local community's leads to the commoditization and commercialization of the hospitality of the local community (Pitana, 2004: 83) .Some opinions say that the presence of culture and tourism are basically two mutually beneficial phenomena. On one side, with the culture potential appeal, tourism will flourish, let alone supported by sociocultural approaches in the sector development. On the

Other hand, with the tourism, steps to preserve cultural values are increasingly intensified and sustained despite the negative view that such efforts seem to promote massive exploitation to the development of cultural values (Hutagalung., 2002: 18 ).

\section{Community-Based Tourism}

Community-based tourism or commonly referred to as community based tourism (CBT), is one of tourism concepts with community or local community placed as the subject's activity. This type of tourism is generally organized on a small scale, which includes interaction between visitors and host communities directly and naturally. Community-based tourism is usually more suitable to be implemented in rural areas, managed and owned by the local community and to local communities, by promoting local tourism service providers and focuses on the culture and environment as its attractions (Asker et al., 2010: 1). Community-based tourism aims to promote participation and ownership of local communities on tourism developed in the region (UNWTO - STEP Foundation, 2011).

Community-based tourism is also a type of tourism in which its development and management are controlled by local communities. Therefore, the bulk of the resulting benefits of tourism are enjoyed by local communities involved directly or indirectly in tourism activities. It also provides education for visitors and local people about the importance of conservation efforts for nature and culture. From those definitions, an operational definition of the concept of "community-based tourism" for this research is a form of tourism that emphasizes ownership and active participation of communities, provides education to local people and visitors, promotes the protection of the cultural and environmental, as well as provide economic benefits to the local community (Hausler and Strasdas 2003: 3).

\section{Tourism Village}

Regarding with village development, there are two important aspects that become the object of development. In 
general, rural development includes two main aspects, namely: (1). Rural development in the physical aspects, namely the construction of the main object in the physical aspect (facilities, infrastructure and human resources) in rural areas such as constructing local roads, houses, settlements, bridges, dams, irrigation, places of worship, education (hardware in the form of educational facilities, and software be any form of regulation, curriculum and learning methods), sports, and so on. Construction on the physical aspect is hereinafter referred as Rural Development. (2) Development in the aspect of human empowerment, the main objects are the development and improvement of capabilities, skills and empower people in rural areas as citizens, such as education and training, fostering of economic, health, spiritual, and so forth. Its main purpose is to help people who are still relatively marginal in order to be free from the shackles of backwardness of social, economic, political and so on. Development in this aspect of human empowerment is hereinafter referred to as the Village Community Empowerment (Muhi, 2011).

One of the example of Village Community Empowerment is tourism village. In this location, there is an effort of rural development and community in the countryside offering the whole atmosphere that reflects the authenticity of the countryside both in social and economic life, social culture, customs, daily life, with the architecture and structure of the village spatial characteristic, or economic activities which are unique and interesting and has the potential for development of various components of tourism, for example: attractions, accommodation, food and beverage, souvenirs, and other travel needs (Soemarno, 2010). Tourism village serves as a community-based Tourism development model. In addition to develop the community in general, it aims to improve the community welfare. Tourism development of rural areas is the impact of the change of interest of tourists to the area a tourist destination. The growing trends and travel motivations of special tourism to return to nature to have interaction with the local community and interests to learn the uniqueness of the local culture encourage tourism development in rural areas. Tourism destination in rural areas refers to a village that provides infrastructure of supporting tourism activities and can be developed into a new tourist attraction (Edwin, 2015).

\section{E. Capacity Building}

Capacity development is an approach that is widely used in the community development. This term has been used since the 1990s by donor countries to improve the capacity of partner countries. In order to understand the concept of capacity building, we firstly need to understand the term. The word "capacity" is often used when we talk about improvement of one's ability, when we obtained the certification, training or participate in education (JICA, 2004). In a broader sense, which is now being used in community development, capacity is not only related to the skills and abilities of individuals, but also with the ability of the organization to achieve its mission effectively and ability to survive in the long term.Most of the literature defines capacity as the ability of the public to carry out something. UNDP defines capacity as the ability (ability to solve problems) that person has, organizations, institutions, and communities to individually or collectively carry out functions, solve problems, and set and achieve goals (UNDP, 2006) .

According to the EU, it is a process of capacity building experienced by individuals, groups and organizations to improve their ability to perform their functions and achieve the desired results (Morgan, 2004). From this definition we can emphasis on two important things: 1) capacity building mostly deals with internal process of growth and development, and 2) capacity building efforts should be result-oriented. United Nation Development Program (UNDP) defines capacity development as a process experienced by individuals, groups, organizations, institutions and communities to improve their ability to: 1) carry out the functions essential, solve problems, set and achieve goals, and 2) better understand and address the needs of their self-development in sustainable wider environment (CIDA, 2000).

From all the definitions above, we can conclude that community development is a process that occurs in the community itself (endogenous process). We, outsiders, cannot develop people, organizations, or the community, but the people inside the community, the organization or the people who can develop themselves. We can only support them by facilitating the process to accelerate their development, as well as helping them find access to resources and inputs they need. Thus, in brief, capacity development can be defined as a process in which people, organizations, and society as a whole, strengthen, create, adapt and maintain their skills as the time goes. It can be concluded that capacity development includes (1). Community knowledge development, (2). organizational leadership development in the community, (3).network of joint ventures development (4). business community development.

\section{RESULT AND DISCUSSION}

Cibuntu is a village located in the district Pesawahan, Kuningan regency, West Java province. The village is right on the slopes Ciremai, the highest mountain in West Java with 3078 meters height above sea level. Hence, the air in the village is very cool and refreshing. Not to mention the hospitality of the villagers who greet every guest who is going to their village, making the visitors increasingly feel welcome to linger in this village. The village looks very green with rice field and forest plants which is preserved well. Besides, in this village, there are archaeological sites that is believed to date back to the old times when the moslem scholar or better known as "wali" heading to Mount Ciremai. Believe it or not, only the villagers know. There are also some megalithic stone tombs in the village. Many hand-held axes were discovered from the tomb stone. The stone axes are now stored in the Cipari Museum. Many archaeological sites are found in the villagers' yard or found far from residential areas. The existence of these sites do not interfere with the villagers' activities. These sites are even well maintained, and some villagers become the caretakers. 
Currently, the village has a population of 1012 people, consisting of 501 men and 511women (based on village population data in 2015). This village has been declared as tourism village-based community in the Kuningan district. With all its potential that has been described previously, this village attracts visitors ranging from local visitors, some private schools to government officials. From the tourism activities, this village has become one of the destinations which directly affects empowerment and well-being of local communities.

This condition cannot be separated from the role of other parties which actively help to achieve community-based Tourism activities. The parties concerned are among other the local people themselselves, the government and Higher Education (Dewi, 2013). In this case, the community serves as central owner of the entire potential of resources of the village, the government are from Pesawahan subdistrict and Kuningan district and Trisakti School of Tourism as a representative of the educational institution that contributes its role in the Tridharma Perguruan Tinggi, namely community service. The role of the higher education are for these following points: (1) To promote integrated attractions for tourists; (2) to develop and market of tour packages to public market ; (3) to provide entrepreneurship training, skills training in tourism related businesses (English language training, hospitality training, cross cultural understanding training, etc); (4) to develop business groups in the community; and (5) to run home stay, culinary, souvenirs, and others (Dewi, 2013). From all the trainings that have been conducted by Trisakti School of Tourism, a very clear improvement is felt by the villagers at Cibuntu, especially on the improved capacity of human resources. Capacity building programs at the Cibuntu is synergized with three responsibilities of Higher Education or Tridharma Perguruan Tinggi, namely Teaching, Research and Community Service.

\section{REFERENCE}

Ali Hanapiah Muhi, (2011), Fenomena pembangunan Desa, Institut Pemerintahan Dalam Negeri, Jatinangor, Bandung-Jawa Barat.

Anwar, (2007), Manajemen Pemberdayaan Perempuan, Alfabeta, Bandung.

Ardika, I.G. 2002.Prosiding Lokakarya Nasional Tahun ekowisata dan pegunungan.Departemen

Energi dan Sumberdaya Mineral.Kementrian Kebudayaan dan Pariwisata.Badan Pengembangan

Kebudayaan dan Pariwisata. Kementrian Lingkungan Hidup. Departemen Kehutanan Jakarta. Hlm. 52

Bungin, M. Burhan. 2003. Analisa Data Penelitian Kualitatif: Pemahaman Filosofis dan MetodeKe Arah Penguasaan Model Aplikasi. Jakarta: PT Raja Grafindo Persada.

Eade, D.1997. Capacity Building : An Approach to PeopleCentreted Development. Oxford UK :Oxfam, GB

Gamar edwin, (2015), Studi tentang pembentukan desa setulang sebagai desa wisatakecamatan malinau selatan hilir kabupaten malinau, jurnal Pemerintahan Integratif.
Gamar edwin, (2015), Studi tentang pembentukan desa setulang sebagai desa wisata kecamatan malinau selatan hilir kabupaten malinau, jurnal Pemerintahan Integratif.

Hardjanto, Imam, (2006) Pembangunan Kapasitas Lokal (Local Capacity Building). Malang: ProgramPascasarjana Universitas Brawijaya.

Harry Hikmat, (2010), Strategi Pemberdayaan Masyarakat, Humaniora Utama Press, Bandung

Isbandi Rukminto Adi, (2013), Intervensi Komunitas \& Pengembangan Masyarakat sebagai upaya pemberdayaan Masyarakat, PT RajaGrafindo Persada, Jakarta.

Jones RG. (2004). Organizational Theory, Design, and Change: Text and Cases, Fourth Edition. New Jersey: Pearson Education, Inc. Upper Saddle River.

Keban, Yeremias. (2004). Enam Dimensi Strategis Admistrasi Publik, Konep, Teori, dan Isu. Yogyakarta: Gava Media.

Lewis, J. (2003). Design Issues. In Qualitative Research Practice: a Guide for Social Science Student Researcher (eds.) Jane Ritchie and Janes Lewis.SAGE Publications, London.

Milen, Anelli. (2004). Pegangan Dasar Pengembangan Kapasitas. Yogyakarta: Pondok Pustaka Jogja.

Moleong, Lexy. (2006). Metodologi Penelitian Kualitatif. Bandung: PT. Remaja Rosdakarya. Bandung.

Made Heny Urmila Dewi, (2013), pengembangan desa wisata berbasis partisipasi masyarakat lokal di desa wisata jatiluwih tabanan, Fakultas Ekonomi Universitas Udayana-Bali.

Peraturan Presiden No. 59 Tahun 2012 Tentang Kerangka Nasional Pengembangan Kapasitas Pemerintahan Daerah.

Pujarsari.M.D. (2003) .Kemampuan Kegiatan Pariwisata dalam Mengembangkan Perekonomian Lokal di Kabupaten Pandeglang.Regional and City Palnning.ITB Central Library. Bandung.

Soemarno, (2010), Desa Wisata, pslp-ppsub.

Soeprapto, H. R. Riyadi, (2003) Pengembangan Kapasitas Pemerintah Daerah Menuju Good Governance.Pidato Pengukuhan Guru Besar dalam Ilmu Administrasi Pembangunan padaFakultas Ilmu Administrasi Universitas Brawijaya.

Sekartjakrarini.S., 1999b. Ekotourisme dasar dana prinsip pengembangan pariwisata. Dalam Prosiding Pelatihan Ekowosata. Memperkuat Perspektif Pemahaman Ekowisata di Idonesia. Yayasan INDECON. Magelang.Hlm.55.

Sekartjakrarini.S., dan N.K.Legoh.(2004). Rencana Strategis Ekowisata Nasional.Jakarta Pusta.Kantor Menteri Negara Kebudayaan dan Pariwisata Indonesia. Jakarta. Hlm. 8.

Sudarto. G. (1999). Ekowisata: Wahana Pelestarian alam, Pengembangan Ekonomi Berkelanjtan dan Pemberdayan Masyarakat. Yayasan Kalpataru Bahari and Yayasan KEHATI. Indonesia. Hlm 84. 
Yuanike. (2013) Kajian Pengembangan Ekowisata Mangrove dan Partisipasi Masyarakat di Kawasan Lembongan Bali.(Disertasi).Intitut Pertanian Bogor.Fakultas Sumberdaya Pesisir dan Laut. Bogor. 